\title{
GEODETSKI PODATKI ZA GEOGRAFSKE INFORMACIJSKE SISTEME
}

\author{
Božena Lipej in Mimi Žvan
}

Izvleček

UDK 528:91:681.3

Prispevek obravnava $v$ prvem delu nekatere pristope pri vzpostavljanju večnamenskih podatkounih baz $v$ geodeziji, $v$ drugem pa praktično izkušnjo avtoric pri pripravi podatkov za unos $v$ geografske informacijske sisteme (GIS) $z$ orodjem EDITOR.

Abstract

UDC 528:91:681.3

SURVEYING DATA FOR GEOGRAPHIC INFORMATION SYSTEM

In the first part the article deals with some approaches in the course of setting up multipurpose databases in surveying, and in the second part it conveys authors' practical experience at the preparation of data entries into geographical information system (GIS) by means of EDITOR tools.

\section{UVOD}

Obdobje izdelave klasičnih načrtov, kart, tabel in spiskov podatkov je v svetu $v$ zadnjih desetletjih $v$ fazi pospešenega tehničnega prestrukturiranja. Razvoj strojnih in programskih orodij, konceptov, tehnologij ter novih znanj se po večletnem časovnem zamiku odraža tudi $v$ slovenskem prostoru. Posamezne stroke so že ugotovile, da sta medsebojno povezovanje in prenos izkušenj predpogoj za uspešno pripravo pilotskih študij in prenosa rešitev $\mathrm{v}$ praktično izvedbo. Tako se $\mathrm{z}$ novimi pristopi ukvarjajo $\mathrm{v}$ znanstvenih in raziskovalnih sredinah, državni upravi, lokalni samoupravi, sektorjih, gospodarstvu in na drugih področjih.

\section{GEODETSKE PODLAGE}

Geodezija kot znanost in stroka se ukvarja s pozicioniranjem objektov oz. $z$ določanjem natančnih lokacij za naravne in grajene elemente zemeljskega površja ter $z$ izkazovanjem le-teh $v$ različnih oblikah in na različnih

Mag. Božena Lipej, Mimi Žvan, MVOUP-Republiška geodetska uprava, Ljubljana 
medijih. Zato so njeni podatki izhodišče za vse nosilce dejavnosti in informacij, vezanih na opredelitve $\mathrm{v}$ prostoru. Dokler osnovni geodetski podatki ne bodo standardizirani in pripravljeni $\mathrm{v}$ digitalni obliki, bodo posamezni uporabniki iskali parcialne rešitve, da bodo lahko začeli svoje podatke uporabljati v lastnih GIS-ih. Ker se s problemi kvalitete podatkov, njihove natančnosti, enotnih definicij, klasifikacij in drugih ponekod ne ukvarjajo dovolj pozorno, bo to lahko $\mathrm{v}$ naslednjih fazah povzročalo precej težav pri medsebojnem povezovanju in prekrivanju tematik (npr.: podatkovni sloj rabe prostora v zemljiškem katastru, topografiji, statistiki, kmetijstvu, okolju ....).

Za vse informacije, vezane na opredelitve $\mathrm{v}$ prostoru, je treba določiti koordinatno lego glede na referenčni okvir, ki ga določa enotna koordinatna mreža s sistemom geodetskih točk. Geodetska služba je v digitalni obliki že vzpostavila podatke reliefa (DMR 100) in teritorialnih členitev prostora (ROTE, EHIŠ), vzpostavlja geodetske točke (položajne in višinske) ter začenja $z$ vzpostavitvijo parcel iz zemljiškega katastra. Pripravljajo se metodološko-tehnološke podlage $\mathrm{z}$ aplikativnimi testiranji zajema in pretvorbe osnovnih elementov topografije (relief, vegetacija, hidrografija, grajena infrastruktura) iz analogne $\mathrm{v}$ digitalno obliko. $\mathrm{V}$ kratkem bo moral biti dokončno pripravljen in verificiran celoten vsebinski, tehnični in organizacijski model sistema geodetskih podatkovnih baz in njihovih podsistemov, ki morajo biti zaradi bazičnosti podatkov o prostoru temelj za izgrajevanje informacijskih sistemov na drugih področjih. Pri vzpostavljanju teh večnamenskih podatkovnih baz bo treba upoštevati načela, ki se nanašajo na uskladitev kriterijev izhodnih produktov, definiranje kategorij prostorskih podatkov, zasnovo zahtevanih ravni natančnosti in oceno podatkovnih virov ter njihove kvalitete. Te podatkovne baze bodo podlaga za zemljiške informacijske sisteme (LIS) - predvsem za parcelno orientirane informacijske sisteme, različne infrastrukturne informacijske sisteme ter informacijske sisteme okolja. Širše pa se bodo te geodetske baze uporabljale za GIS-e (predvsem podsistemi topografske podatkovne baze)

\section{NACIONALNA TOPOGRAFSKA PODATKOVNA BAZA}

Geodetska služba oz. stroka je kot upravljalec teh podatkov zadolžena poleg vzpostavitve tudi za vzdrževanje tako klasičnih oblik kot tudi podatkovnih baz $v$ nastajanju, zato pričakujemo, da se bo za te nove naloge primerno usposobila oz. organizirala. Pri tem je treba zagotoviti tako usposabljanje strokovnjakov, vzpostavitev in vzdrževanje podatkovnih baz kot tudi pridobitev ustrezne strojne in programske opreme. Končni cilj aktivnosti $v$ okviru topografskih razmejitev bo vzpostavitev in vzdrževanje večnamenske nacionalne topografske podatkovne baze $\mathrm{s}$ podsistemi (Lipej 1992), ki so predpogoj za kvalitetno navezavo podatkov in informacij drugih nosilcev (kmetijci, gozdarji, geologi, pedologi ...). Podatkovna baza bo združena oz. korporirana in bo sestavljena iz topološko organizirane grafične ter relacijske atributne podatkovne baze. $\mathrm{V}$ njej bodo predvidoma opredeljene nacionalna, regionalne in lokalne podatkovne ravni, ki se bodo 
predvidoma izražale $z$ naslednjimi pragovi natančnosti: 1:5.000 (oz. 10.000), 1:25.000 do 50.000 in 1:250.000 ter manjšimi.

Selekcioniranje elementov, ki bodo vključeni $\mathbf{v}$ enovito podatkovno bazo, bo odvisno od doseženega kompromisa med strokovno utemeljenimi predlogi ter omejenimi možnostmi finančnih realizacij. Rezultat bo v tem primeru vmesna rešitev med idealno zasnovanimi podbazami in možnostmi praktične realizacije vzpostavitve ter kasnejšega vodenja. Po standardizaciji in verifikaciji projektnih rešitev digitalnih podatkovnih baz se bo predvidoma začelo vzpostavljati podatkovne baze za uporabo na državni ravni. Vzpostavitev in vzdrževanje geodetskih podatkovnih baz - katastrskih in topografskih - predstavlja največji napor in strošek (po ocenah: $70-90 \%$ ) pri vzpostavljanju LIS/GIS-ov, zato sta za nadaljnjo uporabo odločilnega pomena dobra oblikovanost in standardizacija izbranih vsebin. Ker so že dobljeni delni rezultati projektov geoinformacijske infrastrukture, lahko v prihodnje pričakujemo celovite rešitve $z$ zmernim optimizmom.

\section{MEDNARODNE POVEZAVE}

Poleg naporov $\mathrm{v}$ domačih sredinah za zagotovitev medsebojne povezanosti geodetskih in ostalih sistemov bomo morali zagotoviti tudi povezave $z$ evropskim prostorom, kot npr. s CERCO-jem za uradno državno kartografijo, z MEGRIN-om za informacijska omrežja (Salgé 1992), s CORIN-om za okolje in drugimi.

\section{ORODJE EDITOR}

V , nadaljevanju bodo predstavljene nekatere izkušnje, ki smo jih pridobili v eni od samoiniciativnih študijskih nalog. Opravili smo jo $z$ namenom spoznavanja enega od orodij za pripravo oz. obdelavo podatkov za vnos v GIS. Orodje EDITOR, Verzija 1.0., Adacte d.o.o. iz Ljubljane (ADACTA 1992), deluje za uporabnike $v$ prijaznem okolju Windows-ov in je rezultat domačega znanja mladih avtorjev ob sodelovanju sodelavcev Inštituta Geodetskega zavoda Slovenije. Kljub naštetim aktivnostim, ki že potekajo v različnih oblikah na Republiški geodetski upravi, še ne razpolagamo $z$ orodji, ki bi nam omogočala ustrezno pripravo podatkov oz. kasnejšo uporabo $\mathrm{v}$ GIS-ih. Tako je delo $\mathrm{z}$ omenjenim orodjem predstavljalo za avtorici tega prispevka tudi dragoceno praktično izkušnjo.

\section{REZULTATI PRAKTIČNEGA DELA}

Podlaga za testno zajemanje podatkov so bili originali ločenih tematik za temeljne topografske načrte $\mathrm{v}$ merilu 1:5.000 (TTN-5), topografske karte $\mathrm{v}$ merilu $1: 25.000(\mathrm{TK}-25)$ in pregledne karte $\mathrm{v}$ merilu 1:1.000.000 (PK-1000), katerih skrbnik oz. lastnik je Republiška geodetska uprava. Originali teh načrtov in kart so $\mathrm{v}$ izvorni klasični obliki izdelani ločeno 
za posamezne skupine topografskih prikazov, kar olajšuje delo pri osnovnem razdruževanju obravnavanih vsebin. Na področju zajemanja podatkov po ustreznem skaniranju kartografskih originalov so naše izkušnje naslednje:

- Z avtomatsko vektorizacijo je bila na TTN-5, TK-25 in PK-1000 zajeta hidrografija (izjema so dvojne linije in točkovni elementi).

- Pri prikazu reliefa s plastnicami na TTN-5 in TK-25 so bile $z$ editiranjem odstranjene cifre kot ter višin, izvedeno avtomatsko vektoriziranje in po potrebi ekransko editiranje na območjih spajanja prekinjenih plastnic. (Slika)

- Prikaz gozda na TTN-5 in TK-25 je treba obdelati z ekransko vektorizacijo.

- Ceste in železnice je treba ločiti - selekcionirati iz originalov situacije na TTN-5 in TK-25 ter jih ekransko vektorizirati. Na PK 1000 je izdelan prikaz teh linijskih elementov $z$ dvojno črto, ki pa za nadaljnje obdelave ni primerna, zato je treba ekransko določiti vektorsko os cest oz. železnic.

- Stavbe in naselja je treba vektorizirati ekransko, predvsem za stavbe na TTN-5 je uporabna funkcija pravokotnosti.

- Imena (toponime) je treba vzpostaviti dodatno glede na točkovno definiranje pozicij posameznih lokacij.

Dobljeni DXF format standardnega zapisa zajetih podatkov nam omogoča široke možnosti nadaljnje uporabe. Vsem grafično zajetim elementom se v naslednji fazi doda osnovni povezovalni element za bodočo povezavo $z$ atributi (šifra, ime ...).

Uporabniki, ki jih ne zanima le predelava kartografskih podatkov v računalniku sprejemljivejše podatke, lahko uporabljajo orodje EDITOR tudi kot minimizirano GIS orodje. Dodatne funkcije $v$ te namene so še: dodajanje atributov, pretvorba koordinat v Gauss-Kruegerjev koordinatni sistem, združevanje listov, oblikovanje vsebin za izris (imena, fonti, loki ...).

\section{ZAKLJUČEK}

Kombinacija predstavitve dveh tematskih sklopov: splošnih usmeritev za poenotenje geodetskega koncepta vzpostavljanja podatkovnih baz ter aplikativnega dela $\mathrm{z}$ enim od orodij $\mathrm{za}$ pripravo podatkov $\mathrm{za}$ uporabo $\mathrm{v}$ GIS-ih ni zgolj naključna. Odraža nesrečni trenutek stanja na segmentu kreiranja in vzpostavljanja podatkovnih baz $\mathrm{v}$ okviru geodetske službe oz. stroke, ki so ključnega pomena za izgrajevanje informacijskih sistemov drugih uporabnikov ter se kljub številnim naporom zrcalijo $v$ delni nedorečenosti in predvsem $v$ časovnem zamujanju. Naš predlog je, naj ena od pobud simpozija izzveni tudi $v$ smeri večje podpore operacionalizaciji geodetskih podatkovnih baz za čim hitrejšo dodelavo vsebinskih, tehničnih in organizacijskih rešitev ter zagotovitve večletnih namenskih proračunskih finančnih sredstev za izvedbo začrtanih nalog. 
Slika 1: Rezultat avtomatske vektorizacije brez editiranja $z$ orodjem EDITOR za izsek plastnic iz TK-25.

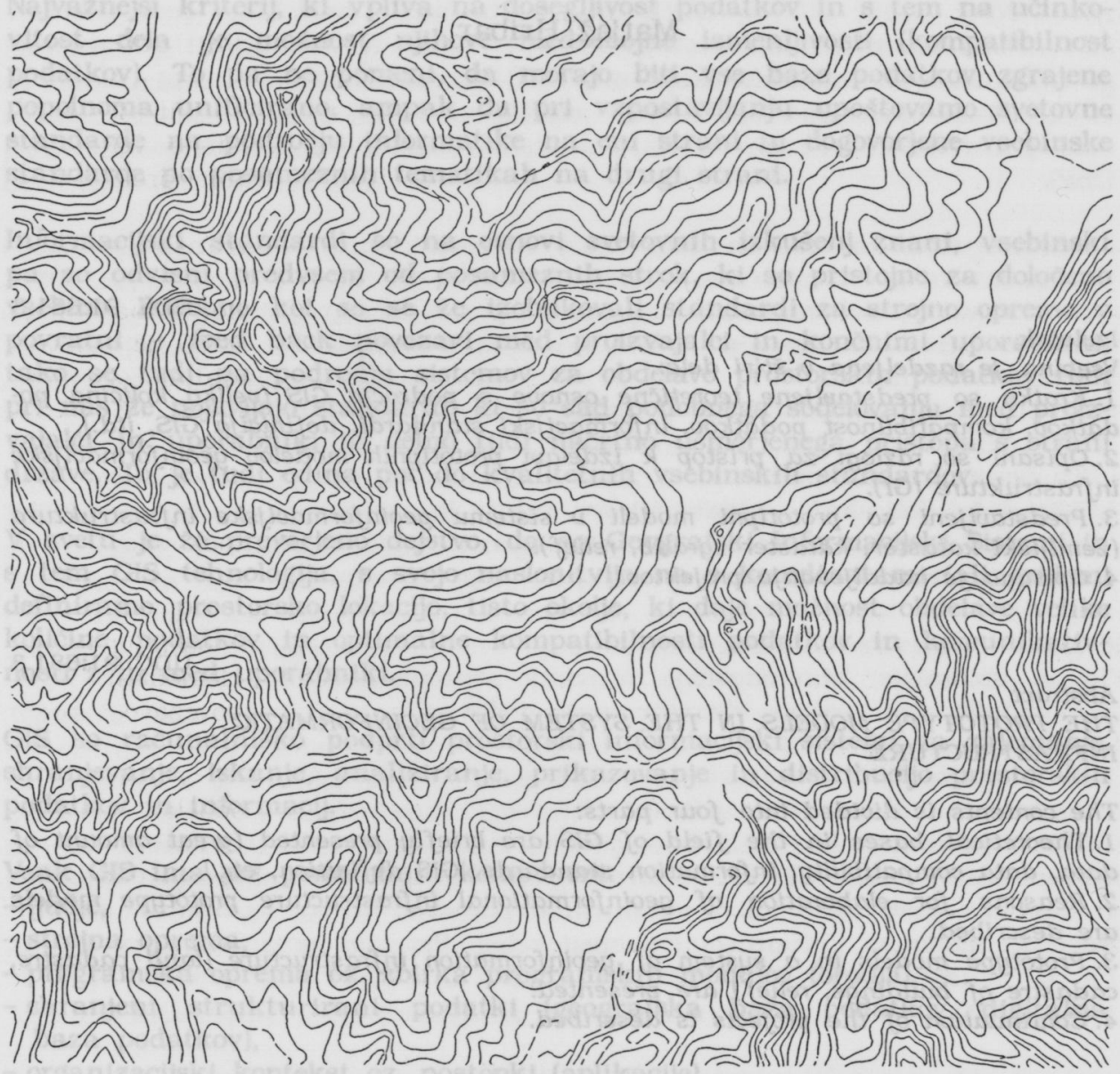

\section{LITERATURA IN VIRI}

Abel, D. J., 1989: A Model for Data Set Management in Large Spatial Information Systems, Int.J. Geographical Information Systems, Vol. 3, No. 4; 291-301.

Adacta, 1992: Uporabniški priročnik za EDITOR - delovna verzija, Ljubljana.

Lipej, B., 1992: Vpliv sodobnih tehnologij in dinamičnih sprememb na oblikovanje prostorskega razvoja Slovenije, XII. Sedlarjevo srečanje, zbornik referatov, Postojna.

Salge, F., 1992: A Geographic Data Interchange Environment for Europe, EGIS'92, Vol. 2; 1502-1511, München. 